\title{
OVERCOMING SOCIAL ALIENATION IN MARXIZM AND POST-INDUSTRIAL THEORY: A COMPARATIVE ANALYSIS
}

\author{
George Putin \\ Postgraduate Student, Odessa I. I. Mechnikov National University, Ukraine \\ e-mail: libertador@bk.ru, orcid.org/0000-0001-6007-5280
}

\section{Summary}

The article is devoted to the reflection of processes in the economy associated with intangible capital on social development. The author focuses on the problem of social alienation, formulated by Marx, and the possibilities of overcoming it, which are opening up in connection with the transition of the economy to the production of intellectual values. Using the method of comparison, the author explores how this problem is solved by representatives of two philosophical trends - post-industrialism (D. Bell, V.L. Inozemtsev, A. Toffler) and neo-Marxism (V.V. Orlov, J. Baudrillard, A.V. Buzgalin, A. Gorz). Both of them believe that the production of knowledge is incompatible with the commodity nature of the industrial economy. However, supporters of the post-industrial concept believe that overcoming the commodity form is possible within the framework of reforming capitalism, while Marxists argue that the «knowledge economy» is achieved only by transforming of social relations. In addition to the actual economic aspects of this issue, the article examines the problems of creative labor, consumer society, relations between people, conflict of values through the prism of alienation.

Keywords: alienation, knowledge, knowledge production, marxizm, post-industrial society, consumer society, postmodernism.

DOI: https://doi.org/10.23856/4622

\section{Introduction}

We live in an era of global economic transformations caused by the spread of a new sphere - the production of knowledge. The old industrial capitalism is moving to the periphery, while the new one - associated with intangible production - is actively developing in the leading capitalist countries. Today, most of the population of developed countries is employed in the service sector and in the creation and processing of information.

The wealth of society has grown many times over: today the intangible capital of leading companies is worth more than their material resources. On this basis, some scholars proclaim a new phase in the development of capitalism, and even its end. A number of economists and philosophers talk about the onset of a post-industrial society, in which the dominant nature of activity will be intellectual creativity. According to the post-industrialists, this society will overcome the main «industrial» forms of social alienation: from the labor process and from the results. The labor process will acquire human features, due to the fact that the production of knowledge liberates the individual, its creative abilities. The inalienability of the results of labor will be based on their inextricable connection with the personality and name of the creator.

However, if some researchers see the overcoming of the division of labor in post-industrial society, then, in the opinion of others, it is to some extent deepening. For example, if earlier the manufacturer himself was engaged in advertising his products, now advertising has become an independent industry, but not self-sufficient, because its goal is the development of 
commodity production. This is evidenced by the fact that advertising in the bulk is commercial, aimed at profit. Whereas social advertising with humanitarian goals is much less common. And so it can be said about any creative activity: it is infected with alienation no less than commodity production.

The phenomenon of knowledge production is, in fact, a continuation of Bacon's thesis «Scientia potentia est». And in recent decades, humanity has advanced in the ability to manage it. However, will this force be directed only for the benefit, and will its excessive production become harmful? The ambiguous mark that knowledge has left in history does not allow speaking about such a phenomenon as its production with absolute optimism. To answer this question, it is necessary to find out what is the nature of the production of knowledge, including the class one.

The answer to the question about the essence of the production of knowledge also depends on whether the capitalization of knowledge, its transformation into a commodity, is possible. Researchers from all directions unequivocally consider the production of knowledge to be something unprecedented, different from the production of more commonplace things. However, as long as commodity-money relations dominate in society, it is hardly possible to completely free intellectual values from the influence of capital. But postindustrialists believe that if the class of knowledge bearers takes power, this will certainly happen. On the contrary, according to the logic of the Marxists, in the conditions of commodity production, intellectual workers will also turn out to be alienated from the results of their labor, the new proletarians.

Although techno-optimists predict a complete victory for the production of knowledge around the world, so far this process looks like a global restructuring of capital, in other words, the transfer of material production to countries with cheap labor. Of course, from the point of view of the distant future, it is easy to predict that knowledge production will gradually take on a planetary scale, spreading to developing countries. The only question is how exactly this process will take place. Post-industrialists believe that in the modern world there is a confrontation between the industrial and post-industrial structures. Leftist theorists insist that post-industrialism is a global form of capitalism, which should lead to its collapse.

Both postindustrialists and Marxists talk about overcoming objectivity, about a more humane way of life that society will enter after the transformative processes that will befall it during the transition to the knowledge economy. The problem of alienation for both those and others is a fundamental question of a person's attitude to the objective reality he creates. Therefore, the purpose of our article is a comparative analysis of the concepts of post-industrialists and followers of Marxism precisely from the point of view of the issue of overcoming alienation.

The novelty of this topic lies in the fact that the process of accumulating knowledge is interpreted as its production, and the role of alienation in this process is analyzed.

This analysis can be divided into four blocks: on the alienation of knowledge - how capitalism affects the content of the produced intellectual product; about the alienation of man from the labor process - here we are talking about the contradiction between the material nature of the production of knowledge and its creative essence; about the alienation of the result of labor - about how the capitalization of the production of knowledge is possible and what processes occur with capital in this case; on social-class alienation - this point examines the state of society in the transition period between the industrial economy and the «knowledge economy». 


\section{The classical theory of post-industrial society by D. Bell and V. L. Inozemtsev}

Theorists of post-industrial society saw the main reason for alienation in the mode of production characteristic of industrial capitalism - a large industrial enterprise organized according to the principle of the division of labor. Man in it was used primitively, as a source of physical energy, while wages were used to restore it, and the main result of labor was alienated in the form of profit. The value was the equivalent of the labor time socially required for the production of goods. According to Daniel Bell, in the new, post-industrial economy, the measure of value will not be socially necessary labor, but intellectual value, inexpressible in terms of commodity-money equivalent (Bell, 1999: 94-95). Mass industrial production will come to naught for two reasons: firstly, it will require less and less human participation due to the development of technologies, and, secondly, the value ratio of goods will collapse, because it is impossible to measure the value of knowledge due to its dissimilarity, heterogeneity and lack of a sane criterion. Intellectual workers form a new class, which, existing in parallel with the old industrial workers, will be the bearer of a completely new social attitude, determined not by income or commodity fetishism, but by the level of education and competence. In the coexistence of two denying value systems, postindustrialists see the main reason for social alienation in the transition period to the future society. Bell hoped that people could be taught new values. This requires appropriate education and upbringing.

Bell's concept is based on the axial principle, which assumes the autonomous existence of the axis of productive forces and the axis of property relations, whereas in Marx they are linked, and the conflict between them creates revolutionary situations. According to Bell, social progress occurs only in the area of knowledge production. All subjects of the historical process that have nothing to do with the post-industrial «movement» are pushed aside, and a progressive role is assigned only to those actors who, in one way or another, promote the technologies and values of the post-industrial world. Therefore, the post-industrial future will not affect the old industrial sector which will be more and more separated by a chasm from the «golden billion», and whose life will deteriorate, and alienation from knowledge as a new institution will be added to the previous forms of alienation. For Bell, the emergence of a new class does not affect the life of the old one, although it poses «questions» to the industrial society. This is where the connection between the two societies is exhausted.

The productive forces in a post-industrial society make a leap, but production relations do not change, in Marxist terminology. At the same time, knowledge does not cease to be a commodity either, since the production of knowledge is, in fact, the same labor, but more qualified, more «noble», that is, not subject to equalization. But money still mediates the process of creating intellectual goods. Therefore, the question remains open whether the production of knowledge will not turn into an ordinary conveyor, and whether intellectual labor will not become a kind of ordinary, measurable labor. In the end, will the cognitariat eventually become the new proletariat $-\mathrm{a}$ class alienated from the results of its work.

And here a lot depends on the subjective attitude of the employee to the labor process. He must be conscious, free from the dictates of someone else's will - here Bell is in complete solidarity with Marx. According to Bell, the production of knowledge is objectively based on the inner freedom of the personality-creator, which excludes external compulsion to work. Thus, among postindustrialists, the concepts of knowledge production and creative labor are synonymous.

Automatism and hierarchy disappear from production relations, nature and artificially created objects are overcome, and only people and their living communication remain. Bell 
denies the division of labor in a post-industrial society; he considers the vertical hierarchy to be outdated. The new organizational structures will meet «the requirements of developing initiative, increasing free time, joint consultations etc.» (Bell, 1999: 461).

Bell's like-minded scholar, the Russian economist Vladislav Inozemtsev, examines a new sociological phenomenon - the knowledge worker. A specific feature of this type of workers is an orientation toward working with information and knowledge, independence from external conditions, professional mobility and, most importantly, a focus on self-realization and self-expression, freedom from material interest. However, Inozemtsev, speaking about independence from external factors of property, in another place defines this independence, rather, as subjective. Since the main motive of creativity is not enrichment, but self-expression of the individual, then «the phenomenon of exploitation can, in our opinion, be overcome rather at the sociopsychological level» (Inozemtsev, 2000: 44).

Information, in fact, will replace capital, since social status will be determined by the degree of actualization, involvement in information flows. There will be no need to compete for the possession of information - it will be available to everyone. Moreover, its reproduction does not require any costs, that is, everyone can take advantage of its benefits. The result of this is overcoming the market, the establishment of more flexible social relations.

Alienation in society will be caused not by exploitation, but by the demarcation of the class of technocrats and representatives of obsolete professions. Intellect, not material possessions, will be the yardstick for social differences. Property differences will also remain, but, as we found out earlier, they will not matter. At least in that part of society where post-industrialism «won». Unlike simple industrial, impersonal labor, the result of intellectual labor cannot be alienated, since it is always associated with the name of the creator, with his personal qualities. Real alienation will be between those who have knowledge and those who do not. Thus, the category of property receives a new content: it no longer means material possession of the means of production based on external compulsion, but the inalienable right to abilities; «Not the sum of material goods, which can be used by everyone who has access to them, but a system of information codes available only to a select few» (Inozemtsev, 2000: 168).

That is, for Inozemtsev, the very specificity of knowledge production by default does not contradict the interests of the individual and denies exploitation. Neither he nor Bell made a distinction between knowledge production and creativity. The second follows from the first and from the fact of overcoming material production. At the same time, the «material» nature of knowledge itself is not considered by them.

\section{Superindustrial society in the concept of A. Toffler}

The American philosopher Alvin Toffler was the most consistent proponent of individualism of all post-industrialists. In his «Metamorphoses of Power», he described the future knowledge society as super-industrial and supersymbolic, a characteristic feature of which is the liberation of capital from material content. The development of money goes to the fact that they first become paper, and then virtual, virtually disappearing from cash. Toffler associated the virtualization of money with the degeneration of mass production and monotonous labor, requiring strict accounting and payment in hard currency. The virtualization of money creates conditions for going beyond commodity exchange and material production, since it becomes possible to create an infinite number of emission centers, and capital turns into speculative, complexly organized and multilevel. But this is a normal process for a society that is moving from a limited material economy to an economy of invaluable knowledge. According to Toffler, 
these facts deal a crushing blow to Marxism and classical political economy, «based on the finite nature of capital» (Toffler, 2003: 87). However, the price of the freedom that comes in connection with the disintegration of mass production is the accelerating dynamics of the new society, leading to the mutual alienation of people from each other. Modern relationships often have the character of fleeting communicative practices that are designed to compensate for loneliness, the poor ability of people to disclose and to establish friendships, and the purpose of which is «to exacerbate emotional relationships at the moment» (Toffler, 2004: 451).

Toffler understood the deep essence of alienation in modern society in accordance with his wave theory, the meaning of which is that changes in civilization are caused by waves, which Toffler identified three: agrarian, industrial and super-industrial. Thus, we are experiencing a phase of collision of two waves of civilization development - the second and the third. The transitional period is fraught with uncertainty - the outgoing era still exists, and the new one has not had time to form. It was in the collision of waves that Toffler saw the reason for a deep split in society and the loss of moral and political guidelines, chaos and inexplicable processes in the modern world. The social and psychological changes caused by the change in the mode of production, Toffler called the shock of the future. For these changes to occur smoothly, society must be prepared for them. It is necessary to adapt, to minimize the rapidity of these changes. This is achieved through knowledge. Toffler called knowledge «the democratic source of power». It promotes the development of relations in society, brings people together, regardless of their property status. Between educated people, he believed, there is much more in common than between the rich, so the development of knowledge will help remove property barriers. In the end, knowledge will replace capital, and then the principle of production will fade into the background, and social utility will become the main priority of the economy.

As we can see, Toffler considered alienation to be a serious problem in a society in transition. However, he connected it not with exploitation, but with the accelerating rhythm of this society, the transition to symbolic money and, as a consequence, to the symbolization of human relations, turning into formal practices. Moreover, an individual who finds himself in a situation of changing waves suffers from a collision with an unusual, with a new world, in which its concepts and its inherent values become an attribute of the past. However, the social alienation of the transition period is a payment for progress and overcoming economic alienation, which, according to the American philosopher, remains in the outgoing industrial era.

Thus, according to post-industrialists, the transition to knowledge production is maturing separately from the industrial society, on a completely new socio-technological basis. The industrial era must leave the arena not as a result of the confrontation of classes and the social activity of the masses, but must simply end. History, therefore, develops linearly. This is the main disagreement between Bell and Inozemtsev and the Marxists. For Marxists, an obstacle to creative work is private property, for Bell's followers - material production.

\section{The concept of the «knowledge economy» in Marxism}

Although Bell and Inozemtsev considered the problems of Marxism and its empirical ground to be outdated, many of the ideas of post-industrialism were already noticed by Marx himself. In «Capital» and other works of the filosofer, there are statements about universal labor, that is, any scientific work, that relies on the work of predecessors. Scientific discoveries are often unclaimed due to the limited productivity of labor. But they remain in science, and over time, the fruits of universal labor are used by «the most insignificant and miserable representatives of money capital» (Marx, 1960: 116). According to V.V. Orlov, Marx considered 
universal labor «a manifestation of the universal creative essential forces of man», thanks to which large-scale and deep forces of nature are involved in production (Orlov, 2012: 70). Orlov believed that there is a direct link between universal labor and «computer labor». Computer labor accumulates scattered efforts in different areas (science, education, medicine, etc.), and, thus, it is the quintessence of universal labor, or, one might say, overcoming the alienation of universal labor. Indeed, the computer has brought us closer to the achievements of «universal labor» by making knowledge available. But can we, on this basis, talk about «the liberation of the universal creative essential forces of man»?

Material production has a clear and understandable goal, namely, the satisfaction of material needs, which are always the same, whereas the production of knowledge is multidirectional and does not have clear criteria and boundaries separating it from information. Thus, it can be considered a «postmodern» phenomenon, or a phenomenon of «late capitalism». The chaotic nature of knowledge in a postindustrial society is uniquely confirmed by Bell himself when he speaks of the division of a single social class into professional groups, or situses.

According to Baudrillard, a person's consumer behavior is determined not by his attitude to the object of desire, but by the system of needs imposed by capitalism, which controls production and consumption as a single process (Baudrillard, 2006: 104). Baudrillard's systems approach allows us to combine the production of knowledge and the production of needs into one whole. This, of course, does not mean that classical education and fundamental science no longer exist. But still they are alienated universal labor.

In a consumer society, the approach practiced in relation to needs becomes standard for all spheres of human activity - science, culture, politics. Social creativity is not guided by ideas, as a reflection of the interests of certain classes, but by beautifully advertised projects created by capital to divert social progress in a direction compatible with the ideology of capitalism. Russian economists A. Buzgalin and A. Kolganov attribute the consumer society to the era of the decline of the «kingdom of necessity» - when knowledge is already becoming a factor in economic growth, but this growth is contradictory: it occurs in «inverted forms». The world of culture takes the form of informational goods - this is how the concepts of «information society», «environmental protection», «sustainable development» and many others that fix the imaginary content of these concepts arise (Buzgalin, 2015: 132). The production of such simulacra is the essence of the production of knowledge as a phenomenon of late capitalism.

\section{Alienation in the production of knowledge and its overcoming by A. Gorz}

Capital directs the development of science in a quantitative dimension, with an emphasis on the production of consumer goods. Since the time of Baudrillard, nothing has changed in this sense: modern capitalism is the most commodity, the most fetishized in history. It still focuses on a person's free time, seeking to organize it around entertainment at the expense of spiritual development. However, according to the post-industrialists, all these are just remnants of the industrial mode of production that persecuted the mass consumer, and in a post-industrial society capital will move away from exploiting human consumption forces, evolving from the production of goods to the production of knowledge. Thus, all human energy will be directed to the development of science and spiritual values. André Gorz, a representative of the philosophical trend of the «new left», polemicized against this point of view. The transition to a knowledge economy, in his opinion, is impossible under capitalism, and the fact that such a prospect is becoming more and more realistic means the imminent end of the power of capital. He wrote that although there are values that are not intended for exchange and cannot have 
a value equivalent, capital is trying to turn it into pseudo-capital by privatizing control over it (Gorz, 2007: 23). The source of the value of knowledge is the restriction of access to it by means of patents, copyrights, licenses, contracts.

The production of knowledge originally arose in the bowels of the industrial economy. It was organized according to the same principles as the production of material goods. Thus, for the first time, a division engaged in intellectual work was created in the pharmaceutical company «Bayer» in 1880. Knowledge had no independent value, but its role was in creating the value of goods, while the material component of their price was insignificant. But this, according to Gorz, laid a mine under capitalism: knowledge, in its essence, is a social value, and cannot be a subject of private property - even instrumental knowledge intended for the purposes of specific production. Moreover, according to Gorz, it is instrumental knowledge in the conditions of production automation that can shake the foundations of the capitalist economy, turning into software that makes it possible to complicate production operations, replacing living labor with dead labor. It is increasingly difficult for capital to alienate knowledge by assigning an exclusive right to use it. The development of means of transmission of information, especially the Internet, makes intellectual values available to everyone. Therefore, today there is a separation of knowledge from the commodity, now it can appear in its pure form and freely circulate.

The separation of intangible production from the production of material goods in capitalism takes place in a contradictory form: on the one hand, capital based on the production of knowledge shows tremendous growth, and here Gorz cites the growth of the stock exchange in the late 90s as an example. However, it ends with crises, which, according to the philosopher, stem from the impossibility of commodity alienation of knowledge, the ephemerality of intangible capital. The market for the intangible is collapsing over and over again - this was shown by the crisis of the early $00 \mathrm{~s}$, after which Gorz wrote that the collapse would be repeated, which, in fact, happened in 2008, after the death of the philosopher. The issuance of consumer loans in an economy dominated by intangible assets leads to an increase in the internal debt of borrowers, which is offset by the external debt of the United States. This testifies to the crisis of a commodity society, the existence of which contradicts the new reality - the diminishing amount of labor required to produce commodities. Commodity capitalism maintains its existence by issuing money based not on the real economy, but on the exchange, that is, fictitious, value, «on their basis, supporting the consumption mania» (Gorz, 2007: 35). According to Gorz, the only way out is the transition to an economy of abundance, in which a decrease in the required labor will be accompanied by a decrease in the amount of money in circulation, that is, a transition to community relations.

Gorz saw the seeds of community relations in the so-called «digital proletariat», or free programmers. Sociology knows examples of young people 30-35 years old who have taken place in the profession, but have already psychologically «burned out», and who do not want to compete for position in the market. Such specialists retire, living on interest and occasionally advising clients, whereas their main activity is working on free software - not intended for the market, but for free use. Gorz wrote that it is free software that promotes the socialization of knowledge and the creation of new opportunities for communication; "free software is a means with which one can build a network, as well as a means of communication, dissemination, socialization and production of knowledge, ideas and activities» (Gorz, 2007: 54). In the free programmer community, he saw the prerequisites for a new economic relationship that denied commodity production. He defined these relations as a «rental society» - a special system of payment for intellectual and creative work. Payment by rent is more efficient than other remuneration systems in that a person is paid all the necessary means of subsistence, regardless of the result of his work. This will help the person concentrate on creativity and not think about satisfying needs. 
Thus, unlike the theorists of post-industrialism, Gorz believed that a contradictory process was taking place in the field of knowledge production: on the one hand, technologies had already developed enough to create inalienable social relations in which wealth would be measured not in the amount of money, but, for example, in free time available; not in the sum of consumer goods, but in creative self-realization. And the shoots of such a society, according to Gorz, already exist. However, capitalism is still trying to preserve the power of money over production, keeping competition and the pursuit of profit as the engines of development, in fact, slowing down this development. The efforts of representatives of large monopolies to curb progress are visible just today. Pavel Durov in a recent article writes about the predatory policy of Apple and Google towards small software manufacturers. Google and Apple have monopolized the app market, forcing smaller developers to pay substantial commissions to list software in the two giants' markets. By what, according to Durov, they stifle innovation in the field of mobile applications. Thus, we see that in the most advanced branch of capitalism - information technology - the usual forms of alienation persist, which slow down the very development of this industry, which, it would seem, lies in the basis of post-industrial society. In general, modern technologies, the Internet, information exchange, electronic payment systems have long allowed transferring the exchange of material goods to a new level, practically eradicating misery. But the use of these opportunities does not go beyond crowdfunding yet.

\section{Conclusions}

As a result, we identified such fundamental differences in solving the problem of alienation among the supporters of the post-industrial society and the philosophers of the left.

Marxists and post-industrialists understood the essence of knowledge production in different ways. Postindustrialists believed that alienation and market necessity were overcome in an economy based on the production of knowledge. The Marxists, on the other hand, believed that under capitalism the production of knowledge is a derivative of the commodity economy, another level of alienation, including not only science, but also sales technologies, marketing, logistics, etc. The weakness of the post-industrialists' position is that they do not distinguish between knowledge and information. They idealize knowledge, speaking about the production of knowledge in general, implying its infinity, its inexhaustibility, independence from the logic of market necessity. Modern Marxists also talk about the decisive role of knowledge production in the economy of the future, in the emancipation of labor. However, this future, they believe, is approaching contrary to the logic of capital, which is trying to materialize the released potential of creativity, to direct the production of knowledge towards the creation of information goods.

Alienation between people has always been the subject of close attention of both Marxists and theorists of post-industrial society. According to the second of them, social exclusion is a conflict of values in the conditions of the transition period from a «factory pipe economy» to a knowledge economy. The main form of this contradiction is the shock of the future, which is expressed in the restructuring of values, misunderstanding in society and depression. At the same time, in the end, the lagging civilization still suffers more, since it is deprived of post-industrial goods and, in fact, turns out to be superfluous, lives poorer and worse. In the end, the bearers of the industrial worldview must be adapted to the new order - then the shock of the future can be minimized. But as the industrialized countries drag down the countries of the golden billion, the confrontation becomes insoluble. Whereas left-wing philosophers believed that the collision of the old with the new, the acceleration of social processes are not in themselves the cause of social alienation. The root of negative phenomena in society lies deeper - in the objectification 
of human relations in the condition of commodity fetishism. The property of capitalism to subordinate the surrounding life to the logic of the commodity causes apathy and individualism. A person, understanding the falsity of reality, full of simulacra and empty shells, sees the values of being only in himself and his loved ones. From the point of view of neo-Marxists, it is the degradation of meaning and goals in modern civilization, the subordination of these goals to material interest that leads to the self-alienation of man and society, be it industrial or post-industrial.

Much can be said about the social function of knowledge in modern capitalism based on the public response to the coronavirus. The state in which the society was and continues to be in a pandemic, in many ways resembles the futuro shock we know. However, it was not possible to calm the people down and reconcile the riots by the methods described by the post-industrialists: we did not see any new breakthrough technologies or effective measures to adapt the population. The authorities' actions to combat the pandemic were half-hearted and ad hoc. The fight against coronavirus was and remains in many ways an imitation, and relied not on knowledge and strategy, but on opportunistic and commercial interests. The pandemic did not unite society, but not because there is still little knowledge about the coronavirus, but rather because real knowledge has been supplanted by information noise. In the world of postmodern capitalism, the social essence of knowledge turns out to be leveled out by its instrumental propaganda function.

The central question related to alienation in Marx concerned the alienation of labor: process and result. In the production of knowledge, there is no alienation of the labor process, post-industrialists believe, due to the specifics of the non-material economy, where the main productive resource will be creativity and the personal abilities of each person. Exploitation remains in modern society only as a dying form of production relations. At the same time, post-industrialists do not separate labor from money and private property, believing that its intellectual orientation is sufficient for overcoming alienation of labor. Nevertheless, as we found out that, although intellectual work itself is not a commodity in the full sense, it is ultimately associated with the production of goods, providing their advertising, delivery, sale, etc. And although it does not disfigure a person physically, like the labor of an industrial worker in the time of Marx, but the commodity orientation of intellectual labor is accompanied by moral alienation and degeneration of the creative principle. Certain professions associated with intangible capital are an example of complete moral alienation and coarsening of feelings, for example, brokers who are ready to sell any dubious asset, regardless of the buyer's risk of losing their last savings. Education and upbringing, on which all the hopes of post-industrialists are largely based, are also struck by alienation in the modern world: for example, the transformation of education into a service leads to the fact that the approach to teaching, judging by the Ukrainian universities, becomes formal, and this negatively affects both educational process and result.

Another form of alienation is associated with a person's attitude to the result of intellectual work. The views of the post-industrialists on this score were based on the connection of this work with a specific person carrying it out, which makes this result inalienable. In the production of knowledge, the main result is creative realization, and the issue of profit distribution becomes secondary. An intellectual product cannot be privatized at all, since knowledge is inalienable in principle due to its general availability and ability to replicate. Marxists, on the other hand, emphasize that in cognitive capitalism there is a system of limiting access to knowledge through patents and intellectual property rights. Private ownership of the production of knowledge turns it into an information commodity, subordinates it to the idea of enrichment and momentary tactical tasks. Although people of intellectual labor live well, receiving a substantial income, knowledge loses its potential on the scale of mankind, as there is an alienation of its uniqueness and social value. Capital is trying to build his monopoly on the sale of brands, 
on brand charm. It is impossible to say for sure how long capital will be able to privatize the intellect and get out of crises, but Marxists believe that the result is the same - knowledge will lose its monetary value and become available to every member of society.

We can agree with some of the predictions of the post-industrialists. They grasped some very important aspects of the future. But the weakness of their concept is that they do not attach importance to social relations. For them, knowledge acts as a neutral and abstract force. Therefore, post-industrialists have no answer to the question of in what direction the transition to knowledge production will take place, and in whose interests it will be carried out. Whether knowledge will contribute to fundamental goals, or will consumer values be created from it. Modernity requires an answer to these questions.

Thus, we have shown what the commodity character of knowledge consists in. The conducted research allows us to conclude that in order to overcome alienation in society through the transition to intellectual work, it is necessary to deny the remnants of the commodity form.

From our point of view, the overcoming of marketability does not occur only on the basis of some ideal properties of intellectual labor, but must be resolved within the framework of social practice. That is, linear progress does not lead to the elimination of commodity alienation - this requires revolutions. Post-industrialists are also not against revolutions, however, for example, Inozemtsev understands by them any coups, as a result of which the country's economy falls into the orbit of the influence of the «golden billion». In our opinion, the goal of revolutions is public ownership of the production of knowledge. And it is impossible without denying the entire commodity economy. Which includes not only knowledge, but also other inalienable values: labor, land, mineral resources, sovereignty, culture, etc.

Further research should show in more detail what the features of knowledge are in comparison with other inalienable resources, and why exactly it should play a decisive role in overcoming alienation at this stage.

\section{References}

Bell D. (1999). Gryadushee postindustrialnoe obshestvo [The coming post-industrial society]. Moscow: Academia. [in Russian].

Baudrillard, J. (2006). Obshestvo potrebleniya [Consumer society]. Moscow: Republic, Cultural Revolution. [in Russian].

Buzgalin A.V., Kolganov A.I. (2015). Globalnyj kapital (3 izd., T. 2) [Global Capital (3rd ed., Vol. 2)]. Moscow: LENAND. [in Russian].

Gorz A. (2007). Znanie, sobstvennost, kapital. K kritike ekonomii znanij [Knowledge, property, capital. To the criticism of the economy of knowledge]. Logos, 4 (61), pp. 5-63. [in Russian]. Inozemtsev V.L. (2000) Sovremennoe postindustrialnoe obshestvo: priroda, protivorechiya, perspektivy [Modern post-industrial society: nature, contradictions, prospects]. Moscow: Logos. [in Russian].

Marx K., Engels F. (1960). Sochineniya (T. 25-1) [Works (Vol. 25-1)]. Moscow: Politizdat. [in Russian].

Orlov V.V., Gritsenko V.S. (2012). Postindustrialnoe obshestvo i problema truda [Postindustrial society and the problem of labor]. Philosophy and Society, 3(67), pp. 60-78. [in Russian].

Toffler E. Metamorfozy vlasti [Metamorphoses of Power]. Moscow.: AST Publishing House LLC. [in Russian].

Toffler E. (2004) Shok budushego [Shock of the future]. Moscow: AST Publishing House LLC. [in Russian]. 